\title{
Optimisation of Centrifugal Speed for PRPBAG®: A Novel Multiple Bag System for Preparing Platelet-Rich Plasma
}

\section{Plateletten Zengin Plazma Eldesinde Yeni Bir Çoklu Torba Sistemi olan PRPBAG® için Santrifüj Hızının Optimizasyonu}

(i) Güven ÇETIN11, id Nang Hseng KYIO1', id Seda TURGUT², id Tuba ÖZKAN33

${ }^{1}$ Bezmialem Vakıf University Hospital, Clinic of Hematology, İstanbul, Turkey

2University of Health Sciences Turkey, Bakırköy Dr. Sadi Konuk Training and Research Hospital, Clinic of Endocrinology, İstanbul, Turkey

${ }^{3}$ İstanbul University-Cerrahpaşa, Cerrahpaşa Faculty of Medicine, Clinic of Hematology, İstanbul, Turkey

\section{ABSTRACT}

Objective: This study aimed to identify the optimal centrifugal speed for the preparation of platelet-rich plasma (PRP) with $\mathrm{PRPBAG}^{\odot}$, a novel multi-bag system.

Methods: The study included 120 (60 women and 60 men) clinically healthy volunteers aged 18-35 years. Participants were divided into three age-sex matched groups according to the centrifugation speeds as follows: $1600 \mathrm{rpm}(\mathrm{n}=40), 1800 \mathrm{rpm}(\mathrm{n}=40)$ or $2000 \mathrm{rpm}$ $(\mathrm{n}=40)$. Whole blood $(150 \mathrm{~mL})$ was drawn from the volunteers, and centrifugation was performed for 10 minutes. After the first spin, the erythrocytes precipitated in the first bag, and the supernatant plasma was transferred into the second bag. Plasma centrifugation was performed at $3500 \mathrm{rpm}$ for 15 minutes. The high-quality PRP product precipitated in the second bag. The supernatant plateletpoor plasma was transferred to the third bag and destroyed. Blood cell count of whole blood and PRP product was measured.

Results: The mean white blood cell level of PRP in the $1800 \mathrm{rpm}$ group was higher than the other groups $(\mathrm{p}=0.027)$. The mean platelet levels were $1005.22 \pm 105.96,1743.7 \pm 145.2$ and $1743.7 \pm 145.2$ $103 / \mathrm{uL}$ in the 1600,1800 and $2000 \mathrm{rpm}$ groups, respectively, after centrifugation $(\mathrm{p}<0.001)$. Accordingly, the platelet yield (fold increase) was significantly greater in the $1800 \mathrm{rpm}$ group than in the other groups $(\mathrm{p}<0.001)$.

Conclusion: This study showed that $1800 \mathrm{rpm}$ for 10 minutes is the optimum first centrifugation speed for preparing PRP with $\mathrm{PRPBAG}^{\circ}$, as it provides an approximately eightfold increase in platelet concentration in PRPBAG ${ }^{\odot}$.

Keywords: Platelet-Rich Plasma, PRPBAG, optimisation
ÖZ

Amaç: Bu çalışmada yeni bir çoklu torba sistemi olan PRPBAG ile Plateletten Zengin Plazmanın (PRP) hazırlanması için optimum santrifüj hızını belirlenmesi amaçlanmıştır.

Yöntemler: Bu çalısmaya 18-35 yaş arası 120 sağlıklı gönüllü (60 kadın, 60 kadın) dahil edildi. Yaş ve cinsiyet uyumlu olarak katılımcılar santrifuj hızlarına göre $1600 \mathrm{rpm}(\mathrm{n}=40), 1800 \mathrm{rpm}$ $(n=40)$ veya $2000 \mathrm{rpm}(\mathrm{n}=40)$ olarak üç gruba ayrıldı. Gönüllülerden $150 \mathrm{ml}$ tam kan alındı ve 10 dakika santrifüj edildi. İlk santrifüjde birinci torbadaki eritrositler çöktürüldü ve üstte kalan plazma kısmı ikinci torbaya aktarıldı. İkinci torba 3500 rpm'de 15 dakika santrifüj edilerek yüksek kaliteli PRP ürünü ikinci torbada çöktürüldü. Üstte kalan plateletten fakir plazma kısmı üçüncü torbaya aktarıldı ve imha edildi. Tam kan ve elde edilen son PRP ürününden kan sayımları yapıldı.

Bulgular: PRP'nin 1800 rpm gurbunda ortalama lökosit düzeyi diğer gruplara göre yüksekti $(\mathrm{p}=0,027)$. Santrifüj sonrası ortalama platelet seviyeleri $1600 \mathrm{rpm}$ grubunda 1005,22 $\pm 105,96103 / \mathrm{uL}$, $1800 \mathrm{rpm}$ grubunda $1743,7 \pm 145,2103 / \mathrm{uL}$ ve $2000 \mathrm{rpm}$ grubunda $1282,2 \pm 105,32103 / \mathrm{uL}$ idi $(\mathrm{p}<0,001)$. Buna göre trombosit verimi (kat artışı) $1800 \mathrm{rpm}$ grubunda diğerlerine göre anlamlı olarak daha yüksekti $(\mathrm{p}<0,001)$.

Sonuç: $\mathrm{Bu}$ çalışmada, PRPBAG ${ }^{\circ}$ ile elde edilen trombosit konsantrasyonunda yaklaşık 8 kat artış sağladığından 10 dakika süreyle 1800 rpm'de ilk santrifüjleme yapılmasının anlamlı olarak daha verimli ve uygun olduğu gösterilmiştir.

Anahtar Sözcükler: Trombositten zengin plazma, PRPBAG, optimizasyon

Address for Correspondence: Güven ÇETiN, Bezmialem Vakıf University Hospital, Clinic of Hematology, istanbul, Turkey

E-mail: gcetin@bezmialem.edu.tr ORCID ID: orcid.org/0000-0002-4265-8105

Received: 28.12 .2020

Accepted: 09.02.2021

Cite this article as: Çetin G, Kyı NH, Turgut S, Özkan T. Optimisation of Centrifugal Speed for PRPBAG®: A Novel Multiple Bag System for Preparing Platelet-Rich Plasma. Bezmialem Science 2021;9(3):351-5. 


\section{Introduction}

Megakaryocytes, the largest cells in the body, are found in the bone marrow. The extensions of megakaryocytes pass into the bloodstream in small pieces to form the body's smallest cells, known as platelets. The primary function of platelets is to prevent blood loss by coagulating damaged blood vessels $(1,2)$. The $\alpha$-granules of platelets are rich in various growth factors, such as transforming growth factor $\beta$, platelet-derived growth factor, insulin-like growth factor, epidermal growth factor and vascular endothelial growth factor that play a crucial role in the acceleration of tissue healing $(3,4)$. Additionally, antimicrobial, anti-inflammatory and analgesic factors could be released by platelets (5). Therefore, the administration of autologous platelets at a supraphysiological concentration could be useful for treatment in many different areas.

Platelet-rich plasma (PRP) is a plasma component obtained by centrifuging whole blood, which contains approximately six to eight times higher platelet concentration than whole blood. This supraphysiological concentration allows the therapeutic use of platelets. PRP is preferred in therapeutic and cosmetic fields, from chronic ulcers to alopecia treatment, because of its positive effects on wound healing (6-8). Recent studies have shown that PRP injections are used in different clinics, including orthopaedic surgery, cardiovascular surgery, neurology, plastic surgery, gynaecology and urology (9-12).

For PRP preparation, blood is taken from a patient and transferred into instruments that contain anticoagulants. Later, it is fractionated by centrifuging. There are more platelets in PRP compared with whole blood. However, there are different separation techniques for PRP preparation, such as centrifugation and filtration $(13,14)$. Also, the volume of blood drawn from the patient in the first place differs. These differences in PRP preparation lead to the obtainment of different platelet amounts. To the best of our knowledge, a standard protocol for the preparation of PRP has not been established yet. Tube methods are widely used to obtain PRP, especially in cosmetics, but they are quite insufficient, especially in patients who need high-quality and high-quantity products. The uncertainty of the use of different methods and high cost of the PRP processing kits limit the widespread clinical use of PRP. In light of these findings, a multi-bag system (PRPBAG ${ }^{\circledR}$ ) was invented to simplify modalities and increase the PRP product's quality and quantity economically.

We aim to identify the optimal centrifugal speed for PRP preparation, which is prepared by $\mathrm{PRPBAG}^{\circledR}$, a novel multi-bag system.

\section{Methods}

\section{Participants}

The study included 120 (60 women and 60 men) clinically healthy volunteers aged between 18 and 35 years. Participants were divided into three age-sex matched groups according to the centrifugation speed as follows: $1600 \mathrm{rpm}(\mathrm{n}=40), 1800$ $\mathrm{rpm}(\mathrm{n}=40)$ or $2000 \mathrm{rpm}(\mathrm{n}=40)$. The range of body mass index (BMI) was $18.5-29.9 \mathrm{~kg} / \mathrm{m}^{2}$, and the groups were also matched for BMI. The local ethics committee approved this study, and informed consent was obtained from all participants individually.

\section{PRPBAG ${ }^{\circledR}$}

$\mathrm{PRPBAG}^{\circledast}$ is a multi (three) bag system that was produced with apheresis bag technology. Its oxygen-permeable feature prevents platelets from remaining in the hypoxic environment. Whole blood (50-150 mL) can be drawn depending on the patient's needs, and the process starts with centrifugation. As detailed in the methodology below, centrifugation is performed in the refrigerated centrifuge specially produced for $\mathrm{PRPBAG}^{\circledast}$. The extractor separates the erythrocytes; then, the remaining product is centrifuged to obtain a high-quality PRP product. All three bags in the system are of the same size and can hold a maximum of $200 \mathrm{~mL}$ of liquid. The separation process is manual and takes place under the supervision of an experienced operator.

$\mathrm{PRPBAG}^{\circledast}$ is a patented multi-bag method and a completely closed, sterile system (Figure 1). All the products used in this method are medical devices authorised for both trade and clinical use by the responsible institution (patent no: TR 201610467 B).

\section{Blood Collection and Preparation steps of PRP}

Whole blood $(150 \mathrm{~mL})$ was directly drawn from the antecubital veins by venipuncture and collected in specially produced PRPBAG. Each PRPBAG ${ }^{\circledast}$ contains $21 \mathrm{~mL}$ anticoagulant solution of citrate phosphate dextrose adenine, USP, to preserve the $150 \mathrm{~mL}$ of whole blood. Of this blood, $1 \mathrm{~mL}$ was used to conduct a complete blood count (CBC) analysis using the Swelab Alfa Plus hematology analyzer.

PRP product was obtained by centrifugation at different spin speeds from blood samples. A double-spin preparation method was applied for all samples using a refrigerated centrifuge specially manufactured for $\mathrm{PRPBAG}^{\otimes}$ (Large Capacity Refrigerated Centrifuge, Inovia Technology INO-FBC 5000). The centrifugation processes were started within $1 \mathrm{~h}$ of blood collection. A flow chart for the preparation of the PRP product with $\mathrm{PRPBAG}^{\oplus}$ was demonstrated in Figure 2.

\section{Centrifugation Process (First Spin)}

Collected samples were placed in the hole of the refrigerated centrifuge. Since mutual balance was essential in the centrifuge, the same weight balances were prepared against the blood collected to prepare the PRP product. Whole blood was centrifuged at 1600 (540 x g), 1800 (684 x g) and 2000 (845 x g) rpm for 10 minutes. Depending on the blood component density, the erythrocytes precipitated in the first bag, and the supernatant plasma was transferred into the second bag with a manual plasma extractor. The third bag remained empty after the first spin. The hose of the first bag, which contained erythrocytes, was separated from the other bags with a hose-closing device and was later destroyed. The process was continued with the remaining two bags. 


\section{Centrifugation Process $\left(2^{\text {nd }}\right.$ Spin)}

The remaining two bags were placed on the hole of the refrigerated centrifuge. The same weight balance was prepared against the opposite level of this hole. The plasma was centrifuged at 3500 rpm $(2587 \mathrm{x} \mathrm{g})$ for 15 minutes immediately. The high-quality PRP product precipitated in the second bag. The supernatant platelet-poor plasma was moved into the third bag with a manual plasma extractor, leaving $10-18 \mathrm{~mL}$ of high-quality PRP in the second bag. The third bag containing platelet-poor plasma was separated and destroyed with the help of the hose-closing device. As soon as the PRP was produced, a $1 \mathrm{~mL}$ aliquot was collected from PRPBAG ${ }^{\odot}$ for blood cell measurements. Blood cell measurements of PRP were analysed using an automated hematology analyzer (Swelab Alfa Plus). European guideline for the preparation, use and quality assurance of blood components has been considered throughout the process (15).

\section{Statistical Analysis}

Statistical analyses were performed using SPSS version 20.0 for Windows (SPSS Inc. Chicago, IL, USA). Values were given as mean \pm standard deviation or standard error according to the distribution of parameters. The associations between groups were assessed by Student's t-test or analysis of variance and Mann-Whitney $U$ or Kruskal-Wallis tests, depending on the number of groups and distribution of data. Dependent variables were analysed with a paired t-test. Numeric values were evaluated using the Kruskal-Wallis test, followed by the post-hoc analysis (Bonferroni correction for all pairs). The categorical variables were assessed using the chi-square test. The threshold for significance was $\mathrm{p}<0.05$.

The number of volunteers included in the study was 36 in each group with a 95\% confidence level and $80 \%$ power, and 40 cases were included in each group.

\section{Results}

The mean age was $26.88 \pm 5.02$ years, and the mean BMI was $23.39 \pm 3.5 \mathrm{~kg} / \mathrm{m}^{2}$ in the study group. Each spin speed group consisted of 20 female and 20 male and age-BMI matched participants. Table 1 presents the $\mathrm{CBC}$ results before the centrifugation of whole blood and the white blood cell (WBC) and red blood cell (RBC) levels from the PRP final product. A comparison of the measurements showed no significant difference in whole blood results among the spin speed groups.
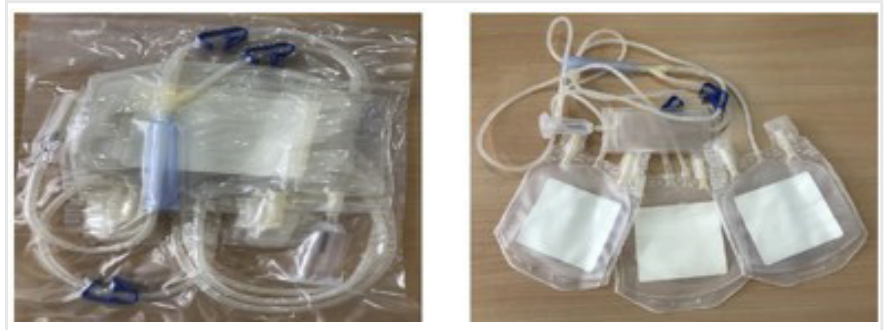

Figure 1. PRPBAG®: a completely closed sterile and multi (three) bag system
On the other hand, the mean WBC level of PRP in the 1800 rpm group $\left(6.5 \pm 0.7710^{3} / \mathrm{uL}\right)$ was significantly higher than in the other groups $(\mathrm{p}=0.027)$. The PRP products contained negligible $\mathrm{RBC}$ concentrations.

WBC levels in whole blood $\left(6.95 \pm 1.3710^{3} / \mathrm{uL}\right)$ significantly decreased in PRP products $\left(3.98 \pm 0.610^{3} / \mathrm{uL}\right)$ in the $1600 \mathrm{rpm}$ group $(\mathrm{p}<0.001)$. WBC levels showed no significant difference before and after centrifugation in the other groups.

Platelet counts were evaluated before (whole blood) and after (PRP) centrifugation (Table 2). The mean platelet levels were $1005.22 \pm 105.96, \quad 1743.7 \pm 145.2$ and $1282.2 \pm 105.32 \quad 10^{3 /}$ $\mathrm{uL}$ in the 1600,1800 and $2000 \mathrm{rpm}$ groups, respectively, after centrifugation process $(\mathrm{p}<0.001)$. Accordingly, statistical analyses revealed that the platelet yield (fold increase) was significantly greater in the $1800 \mathrm{rpm}$ group than in the other groups $(\mathrm{p}<0.001)$.

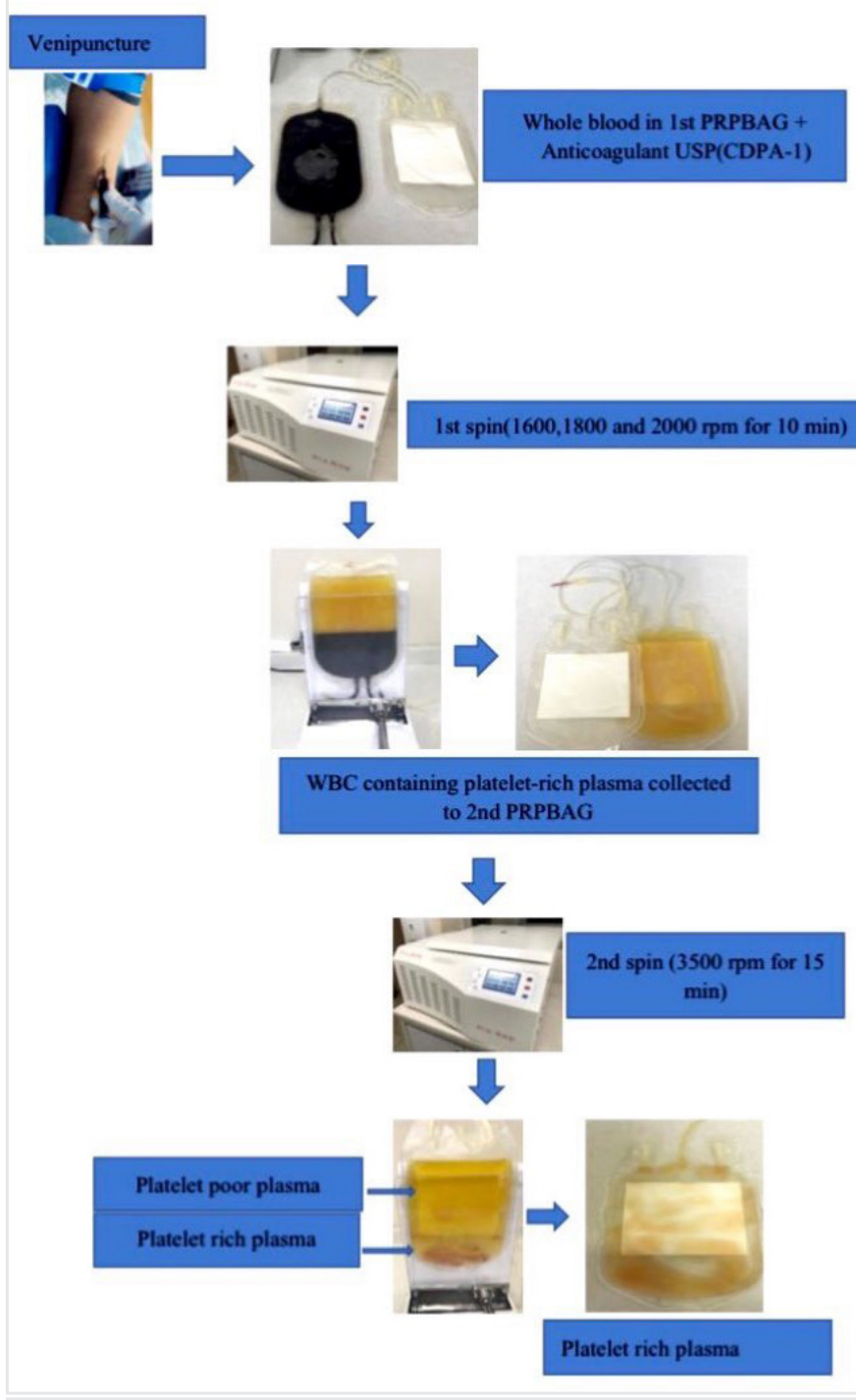

Figure 2. A flow chart for the preparation of platelet-rich plasma product with PRPBAG® 


\section{Discussion}

The use of PRP products in treatments has become an increasingly popular option; many available commercial kits and PRP preparation methods exist. To the best of our knowledge, bag systems are mostly used for blood product transfusions, whereas tube systems are for PRP production. $\mathrm{PRPBAG}^{\bullet}$ system is a novel method for PRP preparation, and this is the first report to compare the first spin speeds to optimise the content of blood cells in PRP produced with PRPBAG from whole blood. Based on the findings of this study, the optimum first centrifugation speed for preparing PRP with $\mathrm{PRPBAG}^{\bullet}$ is 1800 $\mathrm{rpm}$ for 10 minutes. The second spin that follows is $3500 \mathrm{rpm}$ for 15 minutes. We suggest this as an optimal centrifugation protocol for $\mathrm{PRPBAG}^{\oplus}$, as this provides the greatest yield, which is approximately an eightfold increase in platelet concentration.

Centrifugation separates RBCs, WBCs, platelet and plasma, depending on the density gradient of these blood components. WBCs $(1,077 \mathrm{~g} / \mathrm{mL})$ and RBCs $(1,100 \mathrm{~g} / \mathrm{mL})$ centrifuge faster than platelets $(1,058 \mathrm{~g} / \mathrm{mL})$ because they are both heavier $(15,16)$. In an experimental animal study, Shin et al. reported that most WBCs and RBCs precipitate in the bag and separate from the supernatant platelets where the platelet yields depend on the duration and speed of centrifugation. They found the platelet yield to be $6.48 \pm 0.46$ (fold increase) in their optimum protocol. Moreover, they showed that a low centrifugation force and short centrifugation duration could not provide a good separation of platelets, resulting in the low yield of platelets and, therefore, the low recovery rate in animals when the tube method was used for PRP preparation. Prolonged centrifugation force and duration led the platelet yield levels to increase to a certain point; however, the yield started to decrease after the optimum point (17). Consistent with these findings, our results show that the PRP products of the $1800 \mathrm{rpm}$ group reached the best platelet yield at $7.66 \pm 3.49$ (fold increase), and the WBC levels were higher in the $1800 \mathrm{rpm}$ group than in both the 1600 and $2000 \mathrm{rpm}$ groups. Therefore, the optimum protocol for the second spin in our study was $1800 \mathrm{rpm}$ for 15 minutes.

The role of WBCs in the PRP product is controversial, and few studies have evaluated the benefits of WBCs and the interactions between WBCs and platelets on PRP composition. It is suggested that platelets are the main source of growth factors, and WBCs are the main source of inflammatory cytokines (18). McCarrel et al. (19) pointed out that high WBC levels in PRP contribute to inflammatory cytokine expression, and persistent inflammation results in the inferior repair of damaged tissues. On the other hand, Kobayashi et al. reported that growth factor concentration was related to WBC concentrations. Thus, when the number of leukocytes in PRP increases, the quality of the product increases as well (20). They showed that as they performed double centrifugation (first spin $400 \times \mathrm{g}$ for $10 \mathrm{~min}$ and second spin $2000 \times \mathrm{g}$ for $3 \mathrm{~min}$ ), the WBCs reached higher levels than single centrifugation in PRP.

Similarly, we performed double centrifugation. However, our study revealed that the WBC levels decreased in the 1600 and
$2000 \mathrm{rpm}$ groups, but they were stable in the $1800 \mathrm{rpm}$ group. With these findings, other unmeasured and unknown substances released from WBCs could have contributed to the different effects of PRP. Because of this difference, the preparation method of PRP must be assessed separately, and the optimum conditions must be established, especially in medical treatments. Further studies are needed to clarify the effects of WBCs on PRP in different pathologies.

RBCs are the heaviest components of whole blood, and the first spin of centrifugation is especially important to separate RBCs from the other components. Similar to the literature, our study shows that plasma contains negligible amount of RBCs in all of the spin speed groups, namely, 1600, 1800 and $2000 \mathrm{rpm}$, after the first spin of the centrifugation process $[17,21]$.

\section{Study Limitations}

There are some limitations to this study. Firstly, since the PRP samples produced in the study were acquired from healthy volunteers, the recovery levels could not be pointed even though the yield values were revealed. Secondly, the number of groups with different centrifugal speeds could be increased but not to compromise the statistically calculated minimum number of patients and compare a large group of people with the drawn 150 $\mathrm{mL}$ blood. According to the expected usage results, these optimal speeds possibly predicted the best results that were selected by experienced members of our blood bank centre.

\section{Conclusion}

In conclusion, the methods of PRP preparation may directly affect the characteristics of the product. We suggest that the centrifugation initiation with $1800 \mathrm{rpm}$ for 10 minutes is an optimal first spin speed as this method provides an approximately eightfold increase in platelet concentration in PRP products obtained by $\mathrm{PRPBAG}^{\bullet}$ system.

\section{Ethics}

Ethics Committee Approval: Obtained.

Informed Consent: Obtained.

Peer-review: Externally peer reviewed.

\section{Authorship Contributions}

Surgical and Medical Practices: , Concept: , Design: , Data Collection or Processing: Analysis or Interpretation: , Literature Search:, Writing:

Conflict of Interest: No conflict of interest was declared by the authors.

Financial Disclosure: The authors declared that this study received no financial support.

\section{References}

1. Schulze H, Shivdasani RA. Mechanisms of thrombopoiesis. J Thromb Haemost 2005;3:1717-24. 
2. Andrews RK, Berndt MC. Platelet physiology and thrombosis. Thromb Res 2004;114:447-53.

3. Eppley BL, Woodell JE, Higgins J. Platelet quantification and growth factor analysis from platelet-rich plasma: implications for wound healing. Plast Reconstr Surg 2004;114:1502-8.

4. Kaplan DR, Chao FC, Stiles CD, Antoniades HN, Scher CD. Platelet alpha granules contain a growth factor for fibroblasts. Blood 1979;53:1043-52.

5. Mazzocca AD, McCarthy MB, Intravia J, Beitzel K, Apostolakos $\mathrm{J}$, Cote MP, et al. An in vitro evaluation of the anti-inflammatory effects of platelet-rich plasma, ketorolac, and methylprednisolone. Arthroscopy 2013;29:675-83.

6. Nurden AT, Nurden P, Sanchez M, Andia I, Anitua E. Platelets and wound healing. Front Biosci 2008;13:3532-48.

7. Margolis DJ, Kantor J, Santanna J, Strom BL, Berlin JA. Effectiveness of platelet releasate for the treatment of diabetic neuropathic foot ulcers. Diabetes Care 2001;24:483-8.

8. Gkini MA, Kouskoukis AE, Tripsianis G, Rigopoulos D, Kouskoukis K. Study of platelet-rich plasma injections in the treatment of androgenetic alopecia through an one-year period. J Cutan Aesthet Surg 2014;7:213-9.

9. Arshdeep, Kumaran MS. Platelet-rich plasma in dermatology: boon or a bane? Indian J Dermatol Venereol Leprol 2014;80:5-14.

10. Marx RE, Armentano L, Olavarria A, Samaniego J. rhBMP-2/ACS grafts versus autogenous cancellous marrow grafts in large vertical defects of the maxilla: an unsponsored randomized open-label clinical trial. Int J Oral Maxillofac Implants 2013;28:243-51.

11. Adler SC, Kent KJ. Enhancing wound healing with growth factors. Facial Plast Surg Clin North Am 2002;10:129-46.
12. Turan G, Yalçın Bahat P, Aydın A, Yüksel Özgör B. Evaluation of platelet-rich plasma injection activity in the treatment of abnormal uterine bleeding. Turk J Obstet Gynecol 2018;15:222-6.

13. Weibrich G, Kleis WK, Kunz-Kostomanolakis M, Loos AH, Wagner W. Correlation of platelet concentration in platelet-rich plasma to the extraction method, age, sex, and platelet count of the donor. Int J Oral Maxillofac Implants 2001;16:693-9.

14. Aydin F, Pancar Yuksel E, Albayrak D. Platelet collection efficiencies of three different platelet-rich plasma preparation systems. J Cosmet Laser Ther 2015;17:165-8.

15. EDQM. Guide to the preparation, use and quality assurance of blood components. 2017.

16. Brodniewicz-Proba T. Human plasma fractionation and the impact of new technologies on the use and quality of plasma-derived products. Blood Rev 1991;5:245-57.

17. Shin HS, Woo HM, Kang BJ. Optimisation of a double-centrifugation method for preparation of canine platelet-rich plasma. BMC Vet Res 2017;13:198.

18. El-Sharkawy H, Kantarci A, Deady J, Hasturk H, Liu H, Alshahat $\mathrm{M}$, et al. Platelet-rich plasma: growth factors and pro- and antiinflammatory properties. J Periodontol 2007;78:661-9.

19. McCarrel TM, Minas T, Fortier LA. Optimization of leukocyte concentration in platelet-rich plasma for the treatment of tendinopathy. J Bone Joint Surg Am 2012;94:e143(1-8).

20. Kobayashi Y, Saita Y, Nishio H, Ikeda H, Takazawa Y, Nagao M, et al. Leukocyte concentration and composition in platelet-rich plasma (PRP) influences the growth factor and protease concentrations. J Orthop Sci 2016;21:683-9.

21. Fukaya M, Ito A. A New Economic Method for Preparing Plateletrich Plasma. Plast Reconstr Surg Glob Open 2014;2:e162. 